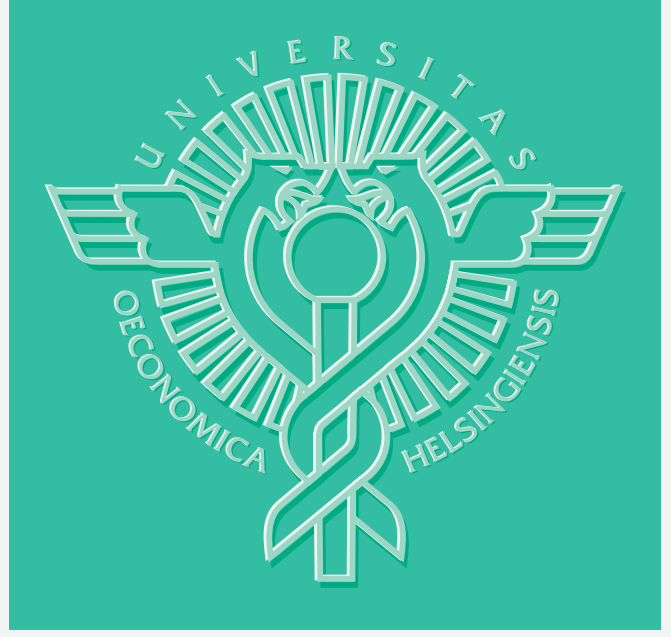

Panu Kalmi

\title{
THE DISAPPEARANCE OF CO-OPERATIVES FROM ECONOMICS TEXTBOOKS
}




\title{
Panu Kalmi
}

\section{THE DISAPPEARANCE OF CO-OPERATIVES FROM ECONOMICS TEXTBOOKS}

\author{
Economics \\ February \\ 2006
}


HELSINGIN KAUPPAKORKEAKOULU

HELSINKI SCHOOL OF ECONOMICS

PL 1210

FI-00101 HELSINKI

FINLAND

(C) Panu Kalmi and

Helsinki School of Economics

ISSN 1235-5674

ISBN 952-488-005-9 (Electronic working paper)

Helsinki School of Economics -

HSE Print 2006 


\section{The Disappearance of Co-operatives from Economics Textbooks}

\section{Panu Kalmi}

Helsinki School of Economics and HECER

\section{Abstract:}

The discussion of co-operatives abounded in the early $20^{\text {th }}$ century economics textbooks, but is virtually absent from their modern counterparts. In this paper, I assemble a dataset of economics textbooks used at the University of Helsinki during 1905-2005 and examine how the treatment of co-operatives has changed, and what factors have lead to the disappearance of co-operatives from economics textbooks. The quality and quantity of the discussion on co-operatives is noted to be much greater in books published before the Second World War than in the post-war books. Possible reasons for the lost interest include changes in the role of the government, the economists, and in the economics paradigm itself.

Keywords: Co-operatives, Textbooks

JEL Codes: A20, B10, B20, P13

Contact information to the author:

\section{Panu Kalmi}

Helsinki School of Economics, Department of Economics

PO Box 1210, 00101 Helsinki, Finland

tel. (+358) 943138283

email: panu.kalmi@hse.fi

Acknowledgements: An earlier version of the paper was presented in the $9^{\text {th }}$ ESHET conference in Stirling, June 9-12 2005. I am indebted to the conference participants and Rod Hill, Derek Jones, Mark Klinedinst, Masashi Kondo, Antti Kuusterä, Jorma Sappinen, Jan Toporowski and Eliisa Troberg for useful comments and suggestions and to Liisa Roponen for help with the language. 


\section{The Disappearance of Co-operatives from Economics Textbooks}

\section{Introduction}

Co-operatives have been an important part of the industrial landscape for the past 150 years or so. In retailing, consumer co-operatives were pioneering the modern retail chains (Furlough and Strikwerda, 1999), and they remain important still in many places in Europe, especially in Scandinavia. ${ }^{1}$ In banking, the market share of co-operative banks at the end of $20^{\text {th }}$ Century was around one-third in countries like France, Austria, Finland and Cyprus (ICA, 1998a). In agriculture, the share of agricultural processing and marketing co-operatives was in many countries close to 100 $\%$ in several sectors. Co-operatives and mutuals remain important in other sectors as well, such as insurance, housing and health care.

The importance of co-operatives is not solely based on their economic significance, as co-operatives also tackle social problems, by alleviating poverty and promoting community development. As democratic organisations managed by their members, they are more accountable to their stakeholders than corporations (Michie and Blay, 2004).

The role of co-operatives in modern market economies can highlight important lessons for students of economics. In today's economics and corporate governance discourse, shareholder primacy is taken as given. Co-operatives during the past two centuries have provided one of the main alternatives to shareholder-based capitalism, and therefore understanding cooperatives is essential to appreciating alternatives to shareholder primacy.

Despite their importance, co-operatives do not receive much attention in current mainstream economics. An indication of this is the neglect of co-operatives in most popular introductory economics textbooks. The typical textbook does not even recognise co-operatives as a form of business organisation, as was revealed in the recent survey of current economics textbooks by Hill (2000). ${ }^{2}$ The importance of textbook contents derives from the fact that textbooks partly define the contours of the discipline. The absence of material on co-operatives in textbooks means that many students do not become familiar with the concept.

The disinterest in co-operatives has not been typical for past economics writers. ${ }^{3}$ In this paper, I provide evidence that co-operatives were well represented in the economics textbooks of the early $20^{\text {th }}$ century. Like Hill (2000), I base my conclusions on a sample of economics textbooks, but instead of focusing on recent scholarship, I compile a longitudinal sample of economics textbooks, covering the entire $20^{\text {th }}$ century. The longitudinal data provide more robust insights on the reasons for the decline and of the current (near) absence of material on co-operatives than could be provided by cross-sectional data. Moreover, this study provides a different angle on 
the disciplinary change of economics. While many studies focus on the changes in research methods (e.g. formalisation of economics), or study the emergence of new subfields, less attention has been paid to what subjects eclipse. Even though the focus here is on textbooks, the paper also contributes to a relatively unexplored topic of the history of economic thought on co-operatives. ${ }^{4}$

The results indicate that the quantity and quality of the discussions related to cooperatives declined markedly after the Second World War. This coincides with several structural changes within the professions: the shift from institutionally-oriented analysis to the neoclassical analysis, the global dominance of US economics, the significant increase in the role of the government in the economy, and the rise of "social engineering”. Towards the end of the paper, I analyse how these various developments have impacted on the treatment of co-operatives in economics textbooks.

The paper is structured as follows. Section 2 outlines the reasons why co-operatives should be of interest to economist. Section 3 describes the data and section 4 the results. In section 5 a more detailed review of the material on co-operatives is presented. Section 6 discusses the reasons for the decline of the study of co-operatives in economics textbooks., and section 7 concludes.

\section{The case for studying co-operatives}

Co-operatives are an economic-organisational innovation known all over the world. The defining features of co-operatives applied in this study $\operatorname{are}^{5}$ :

1) The control belongs to the users (customers, suppliers or workers) of the enterprise;

2) The control rights are exercised democratically, on “one-member, one-vote” basis;

3) Membership is voluntary.

There are three important reasons why co-operatives should be studied in economics courses. First, they are an economically significant actor all over the globe. Second, co-operatives are oriented towards broader social goals that distinguish them from the investor-owned corporation. Third, co-operatives can be used to illustrate important issues in economics.

The economic significance of co-operatives is difficult to define exactly. Estimates on cooperative membership are more readily available than estimates of their contribution to the GDP or employment. The International Co-operative Alliance (ICA) estimated that co-operatives worldwide have around three-quarter billion memberships (ICA, 1998b), and since this figure excludes those co-operatives that are not associated with the ICA, it is likely to be a significant underestimate. Co-operatives are important in the North America, Europe, and Japan alike, as well as in most developing countries, notably India (Birchall, 1997; Hansmann, 1996; Hill, 2000; Klinedinst and Sato, 1994). Examining the role of cooperatives as employers, a recent study on seven European 
countries found that the share of co-operatives in employment provision ranged from around one per cent in France and Portugal to 3.5 per cent in Switzerland (Eurostat, 2001).

Appendix 1 presents some membership statistics for selected countries, drawn from Gide (1922) and ICA (1998b). These figures show that in 1998, the estimated proportion of co-operative membership to the total population in European Union countries hovered around 20-30 \%, and it was even higher in North America. There are also significant commonalities among countries in the incidence of co-operatives. They are common in the food production (agricultural producer cooperatives), retail trade (consumer co-operatives), housing, financial institutions, and health care. But co-operatives have been less successful in the manufacturing sector. Worker co-operatives have generally been less successful than consumer or agricultural producer co-operatives, apart from a few success stories such as the Mondragon Corporacion Cooperativa in Spain (Whyte and Whyte, 1991; Cheney, 1999).

Co-operatives have also social significance beyond their economic role. Through private initiative and mutual aid, co-operatives alleviate poverty and promote the social stability of the communities where they operate (Birchall, 1997; Michie and Blay, 2004). They also support such broad aims of the United Nations as peace and security, human rights, environment protection and gender equality (ICA, n.d.). In short, co-operatives -- unlike investor-owned companies in general -have a broad social mission.

Hill (2000) recommended that economics textbooks should use the existing research on cooperatives as material for textbooks. Papers on co-operatives have discussed topics such as democracy in economic institutions, behavioural differences between co-operatives and traditional firms, incentives and public goods, market failures, and economic systems. ${ }^{6}$ In general, cooperatives provide a systematic alternative framework to the concept of shareholder primacy dominant in many economic and corporate governance discourses, albeit discredited somewhat in the aftermath of Enron collapse and related scandals (Blair, 2003; Deakin and Konzelmann, 2004).

\section{The sample}

In order to study how the coverage of co-operatives has changed in economic textbooks over time, it is necessary to have a broad sample of textbooks on which to base the generalised findings. There are at least two possibilities for compiling such a sample: either to try to identify the major international economics textbooks of various time periods, or to compile a sample of textbooks used in an academic economics curriculum. With the latter method, it is much easier to identify the books that needs to be included in the sample. Selection based on an existing curriculum also reduces the risk of "selection bias”, meaning that the researcher would (deliberately or inadvertently) 
choose books that support his arguments. ${ }^{7}$ For this study, the sample consisted of general economics textbooks used in the University of Helsinki, Finland, between 1905 - 2005. The sample was compiled from the faculty handbooks of the period, and from the survey by Kuitunen and Sullström (1984). Between 1905-45 economics was taught in the Faculty of Law, and thereafter in the newly established Faculty of Social Sciences. One advantage of basing the sample on textbooks used at the University of Helsinki is that the books originated from several countries instead of just one country, as might have been the case if the sample were been drawn from a US, UK or French university.

On the basis of the surveyed faculty handbooks, it seems that the current system according to which students are first exposed to a general introductory course and then continue with more specialised topics emerged in Helsinki during the 1950s. From the late 1950s through the late 1970s, students during the first year used Finnish and Swedish textbooks, and in the second year a general textbook in English (first Boulding, then Lipsey). However, the reason for this was perhaps not so much the differences in the substance of the text, but rather the limited language skills of the first year students. Therefore, the above-mentioned American texts are included in the analysis as introductory texts.

Among the textbooks of the first half of the $20^{\text {th }}$ century, there were books were used for both the introductory course and the advanced course, making it difficult to classify these. I decided to select to the sample broad general textbooks from that period, but excluded texts that were clearly more advanced and theoretical for their time, despite being general economics books (Wicksell's Lectures on Political Economy is an example).

If a Finnish translation of a book was used in teaching, I have also used the translated version. This applies mostly to the period prior to 1945, when most books were translated. Typically, modifications made to the Finnish editions were minimal, consisting of the addition of occasional footnotes etc.

The detailed information on the books, including the edition used in the survey, the original edition, the original title, year of adoption for teaching purposes and the duration of usage are given in the list of references (primary sources). It should be noted that the year of publication refers to the year of publication for the particular edition used in this study, and not to the first edition or to the year when the text was adopted for teaching purposes. There have been multiple editions for most of the books, and often the version used for this study was not the original. The selection rule was simple: the edition that was most readily available from the university libraries in Helsinki was used. The potential bias arising from this procedure is not likely to be substantial, as 
typically only minor modifications occur between successive editions. Furthermore, the edition that is easily available is also likely to have been used in teaching.

\section{[INSERT TABLE 1 AROUND HERE]}

The survey sample consists of 24 textbooks (Table 1), and is comparable in size to Hill (2000), who used 17 current textbooks in his survey. The books can be divided into three different groups: the first group consists of foreign books which were used in teaching mostly between 1905 and 1925. These originated from various continental European countries and represented mainly institutional orientation. The second group consists of Finnish and Scandinavian books, that were adopted in use mainly between 1925 and 1957. In this period, Finnish economics was moving away from German Historical School towards the neoclassical economics of the Stockholm School led by Wicksell, Myrdal, Ohlin, Cassel and others (Paunio, 2002). The adoption of Boulding's text as course material in 1957 marked the beginning of the use of Anglo-American textbooks, although it was not until the early 1990s that an Anglo-American textbook became the primary introductory textbook (Begg et al.). ${ }^{8}$ Table 1 gives the breakdown of the textbooks according to their origin and year of publication.

Thus, in addition to the Finnish and Scandinavian texts that are well represented throughout the period, two distinct groups emerge: the early $20^{\text {th }}$ century institutional texts and the neoclassical Anglo-American textbooks. Since this shift from the historical-institutional approach to the neoclassical analysis has taken place also elsewhere, the findings of this study can probably be applied to other settings as well. Second, while there are no continental European texts that originate from the post-war period, ${ }^{9}$ this may not necessarily bias the results, because American textbooks have influenced economics education in Europe in the post-war period (Backhouse, 2002), and I would expect to get similar findings even with continental European post-war textbooks included in the sample. In the descriptive part of the analysis (see section 5), I also refer to two US textbooks popular in the early $20^{\text {th }}$ century, to show that the discussion on co-operatives was not limited to European books at that period.

\section{The coverage of co-operatives in economics textbooks}

This section presents the results of a quantitative analysis of economics textbooks. The method was to carefully review each selected textbook and count the pages discussing cooperatives. The smallest unit of measurement is a quarter of a page ( 0.25 p.). Even a passing 
mention of co-operatives was valued as 0.25 p. However, in instances where various aspects of cooperatives were discussed in detail, I did not count passing notes to co-operatives.

I used the definitions of co-operatives outlined in section 2 in deciding the types of cooperatives to include. Relatively uncontroversial were the commonest forms of co-operatives: Consumer co-operatives, various types of agricultural co-operatives, worker (producer) cooperatives, co-operative financial institutions, and other established forms of co-operation (e.g. housing and construction co-operatives). I also included mutual insurance societies and building societies, because they typically are member / user -controlled and therefore conform to the notion of co-operatives, even though they typically are not co-operatives in form.

There were some topics which I excluded from the main body of analysis, because they did not strictly confirm to the definition of co-operatives, as defined above. However, in my view these sufficiently resembled co-operatives to be reported in the table as "related issues". These include:

1) Various forms of savings banks, in which control typically does not belong to customers (violate co-operative properties 1 and 2). ${ }^{10}$

2) Profit-sharing and co-partnership (employee ownership), since these typically do not give employees much control and therefore violate the properties 1 and 2 .

3) Collective farms under communism or Yugoslav self-management, since participation in these cannot not be regarded as voluntary (violation of principle 3). 4) Discussions of the Utopian or Christian Socialists or other schools related to cooperative thought, since these deal more with the history of ideas than with cooperatives as institutions.

Table 2 presents the summary statistics on the coverage of various issues on cooperatives in the textbooks. The main result arising from the table is that the textbook coverage of co-operatives in early (pre-1945) period and more recently differs considerably. The mean coverage for the early period was $2.2 \%$ (median $1.7 \%$ ), while on the part of recent textbooks it was $0.2 \%$ (median 0.1\%). The difference in means is statistically highly significant. ${ }^{11}$ Similarly, the mean of the coverage for co-ops and related issues is $3.0 \%$ for early textbooks and $0.2 \%$ for recent textbooks; also this difference is statistically highly significant.

[TABLE 2 AROUND HERE] 
Appendix 2 presents more detailed information on the coverage of co-operatives in various books. The highest coverage is in Conrad, which includes the 47.5 pages on co-operatives (4.6\%) and 72 pages on co-ops and related issues (6.9\%). The second highest is Gide, that includes 33.5 pages on co-ops (4.0\%) and 43.5 pages on co-ops and related issues (5.1\%). In general, books from the early period contain extensive discussion on co-ops. The exception in this regard is Marshall, who devotes only 4.75 (0.7\%) pages of his treatise to co-operatives. However, in the post-war textbooks no author uses as many pages for discussing co-operatives as Marshall, either in absolute or relative terms. Five of the 14 post-war books do not mention co-operative organisations at all, and three of them do not discuss any related issues either (two discuss the Yugoslav selfmanagement).

Another remarkable finding evident from Appendix 2 is that early authors typically examined co-operatives widely, devoting an almost equal number of pages to the main forms of cooperation: co-operative financial institutions, consumer co-operatives, agricultural co-operatives, and worker co-operatives. On the part of the later authors, the most commonly reviewed topic is cooperative financial institutions (or credit co-operatives), but this in practice amounts to a passing mention. Worker co-operatives are not examined by any post-war author. With regard to related issues, socialist organisations resembling co-operatives is the most frequent topic: three of the discussions relate to Yugoslavia, and two to Soviet collective farms.

\section{A detailed look into the material on co-operatives}

\subsection{Early textbooks on co-operatives}

In this section, I review in more detail the issues the textbooks on co-operatives discuss. There is not much to survey in the more recent books, but early books often covered the topic of co-operatives in much detail. Interestingly, many of the co-operative issues were discussed in the general economics textbooks of the earlier period have later resurfaced in specialised economic analysis. ${ }^{12}$

One of the reoccurring themes in several textbooks was the position of co-operatives in the evolution of economic systems. This aspect was important especially to Gide (1917), who believed that economics does not have universal laws, but there are different stages of economic evolution which call for different institutional arrangements. One interesting section of his book is his discussion of the views of the solidaristic school (of which he himself was a leading member) on the future of the wage system (Gide 1917, p. 738-41). According to this school, the wage system was a useful step in economic evolution, but it had reached the limits of its usefulness. This was because the wage system generates an inevitable conflict between employees and employers: an 
increase in wages leads to a corresponding decline in profits, leading to distrust between employees and employers. Moreover, under the wage system, employees are treated as means rather than ends, in violation to the Kantian personhood principle. ${ }^{13}$

However, there were fundamental difficulties for the co-operatives in abolishing the wage system, as pointed out by Aschehoug in his presentation of the socialist critique of cooperatives (1903, p. 538). Only worker co-operatives challenged the prevailing wage system, but they were rare. Consumer co-operatives were successful, but they reproduced capitalist wage relations, since employees in these co-operatives continued to be employed for a wage. According to the socialist critique, consumer co-operatives did not represent a real change from capitalist labour relations, and thus were only a distraction from the higher, revolutionary aims of the working class. ${ }^{14}$

Authors in the tradition of German and Austrian social conservatism (Conrad, 191113; Philippovich, 1914) perceived co-operatives as having a much more limited scope than Gide. According to these authors, the role of co-operatives was to correct the deficiencies of the existing system by providing work to the unemployed, increasing the level of economic education and entrepreneurship among the working classes, and by providing support to small and weak entrepreneurs. Conrad even considered co-operatives to be of conservative character, protecting workers against revolutionary forms of socialism (1911-13, p. 404).

Several authors stressed the role of co-operatives as a tool for the economically disadvantaged. Gide (1917, p. 464) supported this view in connection with credit unions that enable small producers and artisans to receive credit on favourable terms. Aschehoug (1903, p. 520) emphasised the voluntary nature of the co-operatives as solutions to social problems, thus differing from the collectivists, who preferred to address social problems with state intervention.

Philippovich noted that co-operatives are a tool of the small and weak enterprises and households. Households, farmers and small enterprises can utilise purchasing co-operatives in order to improve their position in the markets. Building societies improve the housing facilities for the poor and lower middle-class. Worker co-operatives promise to turn workers into entrepreneurs; however, as Philippovich noted, worker co-operatives had generally been unsuccessful. In general, co-operatives are voluntary affiliations based on personal bonds among members, and stress the mutual self-help principle (Philippovich, 1914, pp. 255-7).

A central question for many of the writers was why consumer co-operatives were so successful, but worker co-operatives were not. Several textbook authors identified distinct advantages within consumer co-operatives: consumer co-operatives improved the economic organisation of the retail trade, reduced the role and profits of the middlemen, and improved quality 
control. Furthermore, consumer co-operatives flourished during an era when competition in retail trade was weak and consumer protection undeveloped. Several authors concluded that consumer cooperatives had reduced prices and improved the quality of foodstuffs, thereby improving the living standards of the working classes. Again it was Gide who took the argument furthest: he argued that consumer co-operative considerably reduced income differentials and ultimately evened out business cycles (1917, p. 794). However, Conrad (1911-13, p. 386-7) noted that consumer cooperatives are mainly successful in branches where demand is steady and profit-margins small. According to Aschehoug, private traders always survive in niche markets, where risk-taking is rewarded (1903, vol. 1, p. 540-41).

Another much debated question was why worker co-operatives were so rare. Many authors praised the worker co-operatives: for instance, Marshall (1961, p. 305) argued that they promised to solve some of the problems faced by investor-owned firms, notably by improving work incentives and reducing the amount of supervisory work. However, co-operatives suffer from flaws that in the contemporary analysis are called "agency problems". According to Marshall, one of the biggest problems is the recruitment of capable managers. Best managers choose to work for private business where they can have earn more. However, co-operatives may outgrow these difficulties if they succeed in attracting managers with "social temper". The hope for co-operatives lies in the diffusion of better knowledge of the principles of co-operation and an increase in general education (Marshall 1961, p. 305-6). Conrad (p.401) pointed out that the average worker is incapable to fulfil the monitoring role he should perform as co-owner. There is a danger that workers fail to discipline bad managers or, if they find a good manager, may constrain his work unnecessary.

Another problem of worker co-operatives frequently referred to by early textbook writers was the problem of hired labour. Philippovich (1914, 256-7) argued that in profits worker co-operatives can only have a secondary role. Otherwise, the co-operative is tempted to hire nonmember labour at fixed wage and not to extend ownership to new employees, as this would dilute the profit-shares of the incumbent members. This argument, which has become known as the problem of co-operative “degeneration”, was mentioned in several other textbooks as well. ${ }^{16}$ Many textbooks cited also the lack of capital among the working classes as another reason for the relative absence of worker co-operatives.

Conrad (p. 401-2) outlined some preconditions for successful worker co-operatives: these can succeed only in industries where workers have a great deal of expertise in the market in which they operate, demand is steady, workers perform similar tasks, and the monitoring functions are easy. ${ }^{17}$ He mentioned handicraft worker co-operatives as an example for such type of cooperatives. 
In sum, textbooks from the earlier period highlight many of the same themes as the more modern literature on co-operatives, but in some cases the emphasis differs. A common theme of early writers was economic education. A sufficient level of business proficiency was needed to promote co-operatives, but on the other hand co-operatives themselves were educating the working (or agrarian) classes to operate a business. Another issue stressed by the early writers was the collective self-help and voluntary nature of co-operatives that provided solutions to social problems based on commonality of interest rather than coercion.

The early authors also shared the view that the growth of co-operatives had been rapid, and some authors backed this with statistical information. Especially Conrad and Philippovich included very detailed statistics on the diffusion of co-operatives. The attitude of the authors towards co-operatives varied from Gide’s enthusiasm to Conrad's more cautious interpretation, but common among all the authors is a high degree of knowledge on co-operatives and the issues surrounding them.

Since all textbooks used at the University of Helsinki prior to the Second World War were of European origin but the post-war textbooks were often American, it is of interest whether US textbooks of the earlier period included analyses on co-operatives. For that reason, I checked two leading early $20^{\text {th }}$ US textbooks, Ely et al. (1920) and Taussig (1922), where the discussions on co-operatives were indeed shorter than in the average European texts ( $0.6 \%$ in Ely et al. and $1.3 \%$ in Taussig). Furthermore, the analyses often were related to the European experience on cooperatives. However, this does not change the fact that these US economics textbooks did include well-informed presentations of co-operatives and on their role in the economy.

\subsection{Anglo-American textbooks}

The authors of popular US textbooks have had a tremendous role in influencing the research agenda after the Second World War. The earliest North American textbooks used at the University of Helsinki are Boulding (first edition 1941) and Samuelson (first edition 1948). Boulding (1966) does indeed contain some references to co-operatives. He argued that there was “no necessary physical reason” why the factory system was adopted instead of universal application of worker co-operatives. According to him, the reason lies in the "natural differences and capacities of men” (p. 327). In arguing against the viability of worker co-operatives, Boulding thus invokes the Darwinian approach: that the absence of co-operatives is evidence on their comparative inefficiency. ${ }^{18}$

Boulding gives a rather peculiar definition of a co-operative. He defines it "as a corporation [sic] which is financed entirely by fixed-interest securities (bonds) and in which the 
ownership resides with people who buy and sell from it” (p. 331). Unfortunately, this definition is misleading, since typically co-operatives receive equity finance from members, and also incomplete, because it makes no reference to the "one member, one vote" - governance structure.

Further, Boulding goes on to discuss consumer co-operatives. According to him, the advantages are the effective utilisation of scale economies and "untapped reservoir of managerial ability among working classes” (p. 332) - a rather different view from the earlier writers who argued that the pool of managerial talent among the working class was limited. Boulding's argument was related to his original theory on why consumer co-operatives in Europe were more successful than in America. According to him, the rigid class structure in Europe limited the advancement opportunities of working classes in Europe, who could advance primarily via cooperatives, while in the US any worker was a potential entrepreneur.

Whatever the merits or defects of Boulding's analysis, his examination of the subject was more extensive than that of successive authors. Samuelson's Economics had a tremendous impact on all post-war textbooks, and probably the neglect of co-operatives in Samuelson also contributed to the neglect of the topic in general. Of the surveyed texts, Samuelson (1970) was the first to have omitted co-operatives from the list of business organisations that included proprietorships, partnerships, and corporations (ch. 5 on Business Organization and Income).

In contrast to Samuelson, Lipsey (1980) included a page and a half discussion of agricultural co-operatives. He used co-operatives to illustrate the proposition that producers benefit from restricting output: "We shall call an association formed for such a purpose a producer's cooperative” (p.290). Later he described the potential instability of such an arrangement. Thus the reader is taught that the co-operative is another name for a cartel, that the establishment of cooperatives raises producer prices while decreasing consumer welfare, but fortunately as there are destabilising tendencies that undermine co-operatives' existence prices return to their competitive levels. Although this description is hardly meant to be a realistic picture of co-operatives, such characterisations are likely to influence the readers' views on co-operatives. There are no institutional discussions apart from a comment that cocoa producers in West Africa, wheat producers in North America, and coffee growers in Brazil have organised co-operatives (p. 289). A more institutionally oriented examination could have pointed out that even though co-operatives are influential in certain agricultural sectors in many countries, their role in price setting is likely to be limited. Import regime and government regulations on agriculture are much more likely to be the determinants of agricultural prices than domestic organisational arrangements.

Begg et al. (1994) mention building societies three times in the context of money supply, but offer nowhere an explanation of what building societies are, how they differ from 
commercial banks, and why they had not been classified as banks at the time of their writing. The issue of building societies could have been used as an example of the co-existence of alternative organisational forms in the financial sector, with the societies having different competitive advantages and disadvantages from the commercial banks. The lack of understanding of these issues has been further reflected in the UK demutualization wave (Cook, Deakin and Hughes, 2002).

Finally, Baumol and Blinder (1988) made no mention to co-operatives or credit unions, even though the book covers the experience of the Yugoslav self-management with a pagelong analysis.

\subsection{Post-war Finnish and North European Textbooks}

This category of textbooks contains 4 books of Finnish origin, 4 Scandinavian, and 1 German-Swiss (Röpke was German in origin, but published the book while in exile in Switzerland). Welinder (1953) contained the most extensive coverage on co-operatives, 3 pages. ${ }^{19}$ Apart from the introduction of the common forms of co-operation, he also used consumer and agricultural cooperatives as examples in reference to economies of scale (p. 64-5). According to Welinder, consumer co-operatives have been useful in promoting competition in monopolised industries (p. 149, 168-9). Similarly, the book by Leppo (1952) included the same amount of reference to cooperatives in relative terms (1.25 pages or $0.6 \%$ ), consisting of a short definition (p. 47-8), as well as the comment that consumer co-operatives are useful in restricting monopoly power (p. 61), plus a mention of credit unions (p. 84). The other books from the 1950s-1960s contain, at most, short definitions.

Of the three more recent books published in the 1970s and 1980s, only Delander and Edebalk (1983) include a note on co-operatives. Thus the decline of co-operatives in economic education is not solely caused by the adoption of Anglo-American textbooks, but also by the fact that the Scandinavian textbooks reduced further their coverage of the subject towards the end of the $20^{\text {th }}$ century. But as the Scandinavian textbook writers often modelled their works on the AngloAmerican textbooks, there could be an indirect link.

In sum, both the quantity and the quality of the discussions on co-operatives deteriorated markedly after the Second World War. Many books overlooked co-operatives altogether. The rest had occasional topic coverage but these were either not very informative, or at worst downright misleading. In this respect, the North European and North American books do not differ much.

\section{Reasons for the decline}




\subsection{Changes in the economic importance of co-operatives}

In this section, I present and evaluate some hypotheses as to why the discussions of co-operatives dwindled in economics textbooks. As mentioned in section 2, it is difficult to properly understand how the economic importance of co-operatives has changed over time. The statistics, presented in the Appendix 1, clearly do not support the hypothesis that the impact of co-operatives has declined since membership figures have mostly increased relative to the population. However, membership is an imperfect indicator of the importance of co-operatives. The decline of the agricultural workforce during the $20^{\text {th }}$ century has also reduced the economic importance of co-operatives, and in some countries has also adversely affected the co-operative financial institutions. The track record of consumer co-operatives in Europe has been uneven: they have declined in importance in some countries (UK, France, Germany), while in others they are among the largest operators in the retail business (Scandinavia). It is also possible that in the early $20^{\text {th }}$ century, the authors expected more from the development of co-operatives than has been realised. In particular, worker cooperatives have remained marginalised. However, it is unlikely that the declining economic importance of co-operatives is the main reason for their neglect.

\subsection{Change in textbook orientation from institutionalism to neoclassical economics}

Economics as a field of study has changed dramatically during the past 100 years, especially in terms of research methods due to developments in mathematical and econometric analysis and, to a lesser extent, in terms of the research topics. There has been a shift from institutional analysis to the more theoretical neoclassical analysis. The systematic historical descriptions presented in the early books have disappeared from modern textbooks. However, even this change should not be exaggerated. The early books were not atheoretical, and the modern books, especially the North American ones, do contain much institutional discussion. A good example is Samuelson (1970). The book contains a chapter on business organisations, which contains institutional analysis only. Co-operatives could have been mentioned there. There is also a chapter on labour and industrial relations (ch. 7) that also contains an exclusively institutional discussion, including a long section on the development of US industrial relations. Samuelson even covered in a half-page discussion the Knights of Labor, a working class-organisation in the late $19^{\text {th }}$ century (p. 128), but failed to mention that the promotion of co-operatives was an important part of their programme (Jones, 1979; Aldrich and Stern, 1984). There is also an institutional chapter on the banking system (ch. 16), but again with no mention of co-operative financial institutions.

However, the change from institutionalism to neoclassical analysis could have another, indirect influence. Typical in the $19^{\text {th }}$ century and early $20^{\text {th }}$ century institutionalism was the 
perception that the economic theories were not universal, but that their applicability varied across historic contingencies (Hodgson, 2001). Similarly, it was perceived that the set of economic institutions varied within different societies and historic periods. This is most evident in the economic thinking of Marx, but the same thought was shared also by non-Marxian analysts, notable Gide. ${ }^{20}$ It is worth remembering that the joint-stock company gained popularity only relatively late in the $19^{\text {th }}$ century (Everett and Minkler, 1993), so that it was still a relatively novel innovation in the early $20^{\text {th }}$ century. Thus, the earlier economists could have perceived co-operatives becoming more common in the organisational landscape of the future. By contrast, recent neoclassical literature treats the current institutional set-up, where co-operatives are believed to be scarce, as more or less fixed.

\subsection{The growth of the government and social engineering}

The role of government changed completely in the $20^{\text {th }}$ century, as the government assumed various tasks such as demand management through macroeconomic policies, regulation of industries, and the production of public goods and various social services. This led to a significant growth of the economic importance of the public sector (Offer, 2001; Lindert, 2004).

In the early $20^{\text {th }}$ century, co-operatives had responded to economic problems that were later shifted to the public domain. As was stressed in various textbooks, consumer co-operatives sold unadulterated goods at a time when consumer protection was minimal. Credit co-operatives reacted to the capital market imperfections and monitoring difficulties at a time when a large majority of population had no alternative access to credit. Housing co-operatives provided inexpensive but good quality housing, financial co-operatives provided credit at affordable interest rates. Both of these elements were combined in building societies. As government regulation in these industries developed, many of the obstacles in these markets were removed (Hansmann, 1996). Even though regulation did not make the co-operatives redundant, it reduced the need for private sector solutions.

Along with the changing role of the government, the role of the economist also changed. Economists became to be seen as experts whose advice was essential in societal decisionmaking, exerting their influence through the government institutions. Planning and regulation became the trade of the economist (Backhouse, 2002, p. 308). The neoclassical paradigm in economics with its emphasis on "optimal” solutions to social problems supplied the tools for the "social engineering" approach, and the increased role of the state in economic affairs provided the means of intervention. This was another instance where the shift from institutionalist-historical 
analysis to neoclassical economics and its focus on universality and optimality reduced the appeal of the co-operative approach.

Practical applications of this stance began to be common in competition analysis, where regulation and cartel-busting became to be seen as the only viable solutions. Solving the problem through consumer ownership was forgotten. Another example is development economies, where development planners became obsessed in bridging the "investment gaps" (Easterly, 2001). Top-down approach replaced the co-operative solutions with the local inhabitants for decades. Little emphasis was given to institutional variation. After the Second World War, the dominant assumption in the provision of social services in UK as well as elsewhere was that the providers of public services were benevolent and well informed, and the recipients of the services were expected passively to accept the quantity and quality offered (Le Grand, 2003). These exemplify what Ellerman (2005) called the direct approach to aid in the development assistance: top-down intervention aimed at reaching the desired outcome quickly, with the recipient of the aid reacting passively to the stimulus created by the intervention. In contrast, co-operatives represent what Ellerman has termed the "indirect approach": customised solutions utilising the local informational advantages and focused on building capabilities. Economists of the early $20^{\text {th }}$ century understood the benefits of self-help and self-education elements of the co-operatives, but since the indirect approach was not consistent with neoclassical economics preoccupied with optimal top-down solutions without institutional variation, it is not surprising that the reference to mutual self-help solutions utilising local knowledge disappeared from the textbooks.

\section{Conclusions}

This paper has examined a range of general economics textbooks used at the University of Helsinki between 1905-2005 to investigate whether the role of co-operatives in economics textbooks has changed. The comparison of the economics textbooks from the early $20^{\text {th }}$ century to the post-war textbooks show a marked shift both in the quantity and quality of material related to co-operatives. Early books are characterised by extensive discussion on co-operatives, theoretical insights, and careful documentation, and they contain a balanced discussions on various forms of co-operation. More recent books are characterised by the absence of any systematic approach to co-operatives and at worst provide misleading information.

The longitudinal material allows to analyse the reasons of this change. The decline seems to be related the changing role of the economist that stress for top-down solutions instead of more local and institutionally sensitive solutions, thus disfavouring co-operatives. This change is related to the shift in economics paradigm from the more institutionally-oriented analysis to 
neoclassical economics with its stress on optimal solutions and downplay of institutional characteristics. Simultaneously, the role of the government in the economy has increased substantially during the $20^{\text {th }}$ century, which has further reduced interest towards privately provided solutions to societal problems.

Although the results were drawn from a sample of textbooks used in Finland, it is likely that the results can be generalised also to other European settings. All the textbooks of the early $20^{\text {th }}$ century in the sample, originating from various European countries, contained discussions on co-operatives. Thus, economics students all over Europe during that period were likely to have had a reasonably firm understanding of co-operatives. After the Second World War, the references to co-operatives became reduce dramatically. This coincided with the adoption of a universal framework for economic analysis. The omission of co-operatives in the Anglo-American textbooks may have contributed to their neglect also in domestic textbooks.

These results have serious implications for the development of the study of cooperatives. If students do not become familiar with the concept of co-operatives during their undergraduate studies, they are also less likely to become interested at a later stage. The unfamiliarity with co-operatives among university graduates is also likely to have an adverse effect on the development of co-operative businesses, since new recruits have no knowledge of their operating logic. The early $20^{\text {th }}$ century authors considered increased economic education to be the prerequisite for successful co-operative business. Even though the general level of economic education has improved, this has had little benefit to the co-operatives, since co-operatives have been forgotten in the curriculum.

Is anything likely to change in this regard in the future? As proposed by Hill (2000), a good way to start would be to integrate some of the current economics research into the textbooks. More material could be available for this purpose, if contemporary economists had a broader interest in co-operatives. Much of the recent economic analysis is on worker co-operatives and particularly on labour-management theory; important practical applications, such as consumer cooperatives or housing co-operatives, have been long neglected. There are also signs that economists are increasing interest on local economic solutions, evidenced for example by the burgeoning economic literature on microcredit (Armendariz de Aghion and Morduch, 2005). If this tendency becomes more widespread, a revival of the study of co-operatives in modern economics may be possible. Moreover, if the "retreat of the welfare state" becomes a permanent state of affairs, there may well also be a need to reinvent the co-operatives as a voluntary and private solution to public problems. 


\section{References}

\section{Primary sources (textbooks surveyed)}

(first edition unless stated otherwise)

Aschehoug, T.H. (1903): Socialokonomik, Kristiania: H. Aschehoug \& Co.

Baumol, William J. and Alan S. Blinder (1988): Economics: Principles and Policy, $4^{\text {th }}$ edition, San Diego: Harcourt Bruce Jovanovich. $1^{\text {st }}$ edition 1979.

Begg, David, Stanley Fischer, and Rudiger Dornbusch (1994): Economics, $4^{\text {th }}$ edition, London: McGraw-Hill. First edition 1984.

Borght, R. van der (1909): Kansantalouspolitiikka, Helsinki: Kansanvalistusseura. Original text Volkswirtschaftspolitik, 1st ed. 1903, Leipzig: Göschen.

Boulding, Kenneth E. (1966): Economic Analysis, vol. 1: Microeconomics. $4^{\text {th }}$ edition. New York: Harper and Row. First edition 1941.

Brisman, Sven (1925): Kansantaloustiede, Porvoo: WSOY. $1^{\text {st }}$ original edition $1911,1^{\text {st }}$ Finnish edition 1917.

Conrad, Johannes (1911-3): Kansantalouspolitiikka, Porvoo: WSOY, 4 vols. Translation according to the 5 th edition in $1910,1^{\text {st }}$ edition in 1897, Jena: Fischer.

Delander, Lennart and Per Gunnar Edebalk (1983): Samhällets ekonomi, Malmö: Liber.

Ingemar Gerhard (1968): Samhällsekonomi. Göteborg: Elanders.

Gide, Charles (1917): Taloustieteen pääpiirteet, Helsinki: Otava (2nd Finnish edition). Original text Principes d'Économie Politique, 13th edition, 1911. $1^{\text {st }}$ edition 1883. $1^{\text {st }}$ Finnish edition 1904.

Harmaja, Laura and Leo (1925): Kansantaloustiede. Helsinki: Otava. 
Korpela, Asko (1978): Taloutemme rakenne ja toiminta. Jyväskylä: Gummerus.

Leppo, Matti (1952): Lyhyt kansantaloustieteen oppimäärä. Porvoo: WSOY.

Lipsey, Richard G. (1980): An Introduction to Positive Economics, London: Weidenfeld and Nicolson. $1^{\text {st }}$ edition 1963.

Marshall, Alfred (1961 / 1920): Principles of Economics. London: Macmillan. $9^{\text {th }}$ (variorum) edition, vol. $1.1^{\text {st }}$ edition 1890 .

Nyboe Andersen, P., Bjarke Fog, and Poul Winding (1962): Kansantaloustiede, $3^{\text {rd }}$ Finnish edition. Porvoo: WSOY. $1^{\text {st }}$ Finnish edition 1953. Original text Nationalökonomi. $1^{\text {st }}$ edition 1952.

Pekkarinen, Jukka and Pekka Sutela (1980): Kansantaloustiede: johdatus perusteisiin. Porvoo: WSOY.

Philippovich, Eugen von (1914): Yleinen kansantaloustiede, Helsinki: Otava. Original text Allgemeine Volkswirtschaftslehre, 10th edition, 1913. 1st edition 1893.

Röpke, Wilhelm (1951): Taloustieteen perusongelmia, Helsinki: Otava. Original text Die Lehre von der Wirtschaft, 1st ed. 1937.

Samuelson, Paul A. (1970): Economics, 8th edition, New York: McGraw-Hill. 1st edition 1948.

Tamminen, Mikko (1967): Talous ja tuotantoprosessi. Porvoo: WSOY.

Westergaard, Harald (1909): Kansantaloustieteen pääpiirteet, Porvoo: WSOY. Original Nationaloekonomien i Hovedtraek, 1st ed. 1908, Copenhagen.

Welinder, Carsten (1953): Ekonomisk Teori och politik, Stockholm: Kooperative förbundet, $2^{\text {nd }}$ ed. $1^{\text {st }}$ ed. 1948.

Willgren, K. (1925): Kansantaloustieteen oppikirja, Helsinki: manuscript. 


\section{Other sources}

Aldrich, Howard and Robert N. Stern (1984): 'Resource Mobilization and the Creation of US Producer Cooperatives’, Economic and Industrial Democracy, 4: 371-406.

Anonymous (1999): Neue Hallsche Genossenschafts-Korrespondenz: das Institut stellt sich vor, Institut für Genossenschaftswesen an der Martin Luther Universität Halle-Wittenberg. Available from http://www.landw.uni-halle.de/igw/band1.pdf

Armendariz de Aghion, Beatriz and Jonathan Morduch (2005): The Economics of Microfinance, Cambridge, MA: MIT Press.

Backhouse, Roger E. (2002): The Penguin History of Economics, London: Penguin.

Birchall, Johnston (1997): The International Co-operative Movement, Manchester: Manchester University Press.

Blair, Margaret (2003): 'Post-Enron Reflections of Corporate Governance’, Journal of Interdisciplinary Economics, 14(3): 113-24.

Bonin, John P., Derek C. Jones and Louis Putterman (1993): 'Theoretical and Empirical Studies of Producer Cooperatives: Will Ever the Twain Meet?' Journal of Economic Literature, 31:1290-1320.

Chamard, John and Tom Webb (2004): 'Learning to Manage the Co-operative Difference', presented in the $12^{\text {th }}$ IAFEP conference in Halifax, Nova Scotia, July 8-10, 2004.

Cheney, George (1999): Values at Work: Employee Participation Meets Market Pressure at Mondragon, Ithaca, NY: ILR Press.

Cook, Jacqueline, Simon Deakin and Alan Hughes (2002): 'Mutuality and Corporate Governance: The Evolution of Building Societies Following Deregulation', Journal of Corporate Law Studies, 2: 110-38. 
Deakin, Simon and Suzanne Konzelmann (2004): 'Learning from Enron’, Corporate Governance: An International Review, 12(2): 134-42.

Dow, Gregory K. (2003): Governing the Firm: Workers' Control in Theory and Practice, Cambridge, UK: Cambridge University Press.

Easterly, William (2001): The Elusive Quest for Growth: Economists’ Adventures and Misadventures in the Tropics, Cambridge, MA: MIT Press.

Ellerman, David P. (1988): ‘The Kantian Person / Thing Principle in Political Economy', Journal of Economic Issues, 22(4): 1109-22.

Ellerman, David (2005): Helping People Help Themselves: From the World Bank to an Alternative Philosophy of Development Assistance, Ann Arbor, MI: University of Michigan Press.

Ely, Richard T., Thomas S. Adams, Max O. Lorenz, and Allyn A. Young (1920): Outlines of Economics, New York: MacMillan, $3^{\text {rd }}$ revised edition ( $1^{\text {st }}$ edition 1893).

Eurostat (2001): 'A Pilot Study on Co-operatives, Mutuals, Associations and Foundations’, Luxembourg: Eurostat.

Everett, Michael J. and Alanson P. Minkler (1993): ‘Evolution and Organisational Choice in Nineteenth-Century Britain’, Cambridge Journal of Economics, 17: 51-62.

Furlough, Ellen and Carl Strikwerda (1999, eds.): Consumers Against Capitalism? Consumer Cooperation in Europe, North America and Japan, 1840 - 1990, Lanham, ML: Rowman \& Littlefield.

Gide, Charles (1922): Consumers’ Co-operative Societies, New York: Alfred A. Knopf. Hansmann, Henry (1996): The Ownership of Enterprise, Cambridge, MA: Belknap Press. 
Hill, Roderick (2000): 'The Case of Missing Organizations: Co-operatives and the Textbooks', Journal of Economic Education, 31(3): 281-95.

Hodgson, Geoffrey M. (2001): How Economics Forgot History: The Problem of Historical Specificity in Social Sciences, London: Routledge.

ICA (1998a): 'Statistics and Information on European Co-operatives’, Geneva: International Cooperative Alliance.

ICA (1998b): Latest ICA Statistics of July 1, 1998. Geneva: International Co-operative Alliance. Available from http://www.coop.org/statistics.html

ICA (n.d.): 'How the ICA Contributes to the Aims of United Nations', Geneva: International Cooperative Alliance. Available from http://www.wisc.edu/uwcc/icic/orgs/ica/un/contribute.html

Jones, Derek C. (1976): 'British Economic Thought on the Associations of Labourers, 1848-1974', Annals of Public and Co-operative Economics, 47(1): 5-36.

Jones, Derek C. (1979): 'U.S. Producer Cooperatives: The Record to Date’, Industrial Relations, 18: 342-57.

Jossa, Bruno (2005): 'Marx, Marxism and the Cooperative Movement', Cambridge Journal of Economics, 29: 3-18.

Klinedinst, Mark and Hitomi Sato (1994): ‘The Japanese Cooperative Sector’, Journal of Economic Issues 28(2): 509-17.

Kuitunen, Tero and Risto Sullström (1984): 'Kansantaloustieteen opetus, tutkintovaatimukset ja väitöskirjatutkimus Helsingin yliopistossa 1906-82’. In Heikki Koskenkylä, Jukka Pekkarinen, Antti Räikkönen and Pentti Vartia (eds.): Sata vuotta suomalaista kansantaloustiedettä. Vammala: Vammalan kirjapaino.

Le Grand, Julian (2003): Motivation, Agency and Public Policy: Of Knights and Knaves, Pawns and Queens, Oxford: Oxford University Press. 
Lindert, Peter H. (2004): Growing Public: Social Spending and Economic Growth Since the Eighteenth Century, Cambridge: Cambridge University Press.

Michie, Jonathan and Jonathan Blay (2004): Mutuals and Their Communities: How One in Three Enjoy the Mutual Advantage, London: Mutuo.

Mill, John Stuart (1871): Principles of Political Economy. London: Longman.

Offer, Avner (2001): Why Has the Public Sector Grown So Large in Market Societies? The Political Economy of Prudence in the UK, Oxford: Oxford University Press.

Paunio, Jouko (2002): ‘Suomalaisen kansantaloustieteen kansainvälistyminen’, Finnish Economic Journal, 98 (4): 349-62.

Russell, Raymond (1995): Utopia in Zion: The Israeli Experience with Worker Cooperatives, Albany: SUNY.

Taussig, F.W. (1922): Principles of Economics, vol. II, New York: MacMillan, $3^{\text {rd }}$ revised edition ( $1^{\text {st }}$ edition 1911).

Walter, Karl (1933, ed.): Co-operation and Charles Gide, London: P.S. King \& Son.

Whyte, William Foote and Kathryn King Whyte (1991): Making Mondragon: The Growth and Dynamics of the Worker Cooperative Complex, Ithaca, NY: ILR Press. 


\section{Notes}

${ }^{1}$ According to the ICA (1998a), in 199843 \% of the Swedish population were members of consumer co-operatives. In Finland the corresponding figure was $21 \%$ and 23\% in Denmark. The market shares in 1998 were 36 \% for Finland and $20 \%$ for Sweden (data not available for Denmark). At least in Finland, both the market share and membership figures have risen substantially since 1998.

${ }^{2}$ Co-operatives are also by and large also neglected in management textbooks as well. See Chamard and Webb (2004).

${ }^{3}$ Apart from authors cited here, John Stuart Mill is often cited as an example of an economist with special interest on co-operatives. See especially Mill (1871, book 4, ch.7).

${ }^{4}$ An earlier contribution to the field is Jones (1976), who surveyd the thought of the British economists of the $19^{\text {th }}$ and early $20^{\text {th }}$ century. He concentrated more on worker co-operatives and also included profit-sharing in his survey.

${ }^{5}$ See Hill (2000, p. 282) for a more elaborate list of defining features.

${ }^{6}$ Within modern economics, worker co-operatives have received most attention of all types of co-operatives within the “labour-managed firm” literature, see Bonin et al. (1993) and Dow (2003) for surveys. Hansmann (1996) discussed the research on different types of co-operatives more broadly.

${ }^{7}$ It is of course possible that university professors chose the textbooks to the curriculum that would reflect their pro- or anti co-operatives sentiments. However, I find it unlikely that the discussions on co-operatives would have played a major part in textbook selection in any period.

${ }^{8}$ Samuelson's textbook was never a required text for a university course, although it was "recommended reading” in an introductory course at least during the 1970s. Nevertheless, it is included here because of its prominent role in economics education worldwide.

${ }^{9}$ The original edition of Röpke (1951) dates from 1937.

${ }^{10}$ See Hansmann (1996, ch. 13) for a discussion on the differences between co-operative financial institutions and savings banks.

${ }^{11}$ It can be argued that Röpke (1951) should be classified as a pre-war book, since the original German edition appeared already in 1937 . This would imply that the mean coverage on co-operatives was $2.0 \%$ for pre-war books and $0.2 \%$ for post-war books. The difference in means remains statistically highly significant $(t=3.54)$. Another borderline case is Boulding (1966), the first edition of which appeared in 1941. However, the main lifespan for this book was during the post-war period, justifying its classification as a post-war book.

${ }^{12}$ At least two of the authors were personally engaged with the co-operative movement. Gide's involvement is well known (e.g. Gide, 1922; Walter, 1933). Conrad, late in his career (since 1911 until his death in 1915), was the director of the newly established Institute for Co-operative Studies at the University of Halle (Anon., 1999).

${ }^{13}$ See Ellerman (1988) for a modern analysis of this issue.

${ }^{14}$ Aschehoug (1903) himself was not sympathetic to this criticism, but he did not attempt to refute it. However, he noted that consumer co-operatives had notably improved the living standards of working-class families (p. 539).

${ }^{15}$ Even though agricultural co-operatives and financial co-operatives also received a fair amount of coverage, the texts were mainly concerned with a description of various types of co-operatives and their prevalence, and therefore it is not necessary to repeat that discussion here. 
${ }^{16}$ See Russell (1995) for more historic references and the more recent literature concerning the "co-operative degeneration”.

${ }^{17}$ This list bears resemblance to the issues raised by Hansmann (1996).

${ }^{18}$ Everett and Minkler (1993) have argued against the Darwinian argument. In their view, the worker co-operatives were seriously handicapped by the absence of suitable legislation targeted to their needs in the crucial formative period of $19^{\text {th }}$ century Britain.

${ }^{19}$ His book was published by the Swedish Central Consumer Co-operative (Kooperativa förbundet).

${ }^{20}$ Whether Marx himself saw co-operatives as the transitory means on the way from capitalism to socialism or as useful end, has been under some dispute. See Jossa (2005) for a thoughtful analysis. 


\section{Tables}

Table 1. Breakdown of textbooks according to the publication year and country of origin

\begin{tabular}{|l|l|l|l|l|l|l|}
\hline $\begin{array}{l}\text { Time / } \\
\text { place }\end{array}$ & $\begin{array}{l}1901- \\
1920\end{array}$ & $\begin{array}{l}1921- \\
1940\end{array}$ & $\begin{array}{l}1941- \\
1960\end{array}$ & $\begin{array}{l}1961- \\
1980\end{array}$ & $\begin{array}{l}1981- \\
2000\end{array}$ & Total \\
\hline Finland & 0 & 2 & 1 & 3 & 0 & 6 \\
\hline $\begin{array}{l}\text { Other } \\
\text { Scandinavia }\end{array}$ & 2 & 1 & 2 & 1 & 1 & 7 \\
\hline $\begin{array}{l}\text { Germany / } \\
\text { Austria }\end{array}$ & 3 & 0 & 1 & 0 & 0 & 4 \\
\hline France & 1 & 0 & 0 & 0 & 0 & 1 \\
\hline $\begin{array}{l}\text { Great } \\
\text { Britain }\end{array}$ & 1 & 0 & 0 & 0 & 1 & 2 \\
\hline $\begin{array}{l}\text { North } \\
\text { America }\end{array}$ & 0 & 0 & 0 & 3 & 1 & 4 \\
\hline Total & 7 & 3 & 4 & 7 & 3 & 24 \\
\hline
\end{tabular}

Notes:

1) The time period refers to the publication year of the used in this study, which is not necessarily the first edition.

2) Begg et al. (1994) has been classified as originating from the UK, since the UK edition was used at the University of Helsinki.

Table 2. The coverage of co-operatives in the pre- and post - Second World War periods: summary statistics

\begin{tabular}{|l|l|l|l|l|l|l|}
\hline & Min & Mean & Median & Max & $\begin{array}{l}\text { Standard } \\
\text { deviation }\end{array}$ & $\begin{array}{l}\text { Difference } \\
\text { in means } \\
\text { (t-stat. }\end{array}$ \\
\hline $\begin{array}{l}\text { Co-operatives } \\
\text { only, pre WW } \\
\text { II (N=10) }\end{array}$ & $0.7 \%$ & $2.2 \%$ & $1.7 \%$ & $4.6 \%$ & $1.3 \%$ & $\begin{array}{l}2.0 \% \\
(3.92)\end{array}$ \\
\hline $\begin{array}{l}\text { Co-operatives } \\
\text { only, post WW } \\
\text { II (N=14) }\end{array}$ & $0 \%$ & $0.2 \%$ & $0.1 \%$ & $0.6 \%$ & $0.2 \%$ & $2.8 \%$ \\
\hline $\begin{array}{l}\text { Co-operatives } \\
\text { and related } \\
\text { issues, pre } \\
\text { WW II (N=10) }\end{array}$ & $0.8 \%$ & $3.0 \%$ & $2.3 \%$ & $6.9 \%$ & $2.2 \%$ & $(3.30)$ \\
\hline $\begin{array}{l}\text { Co-operatives } \\
\text { and related } \\
\text { issues, post } \\
\text { WW II (N=14) }\end{array}$ & $0 \%$ & $0.2 \%$ & $0.1 \%$ & $0.7 \%$ & $0.3 \%$ & \\
\hline
\end{tabular}

Note: As a test of statistical significance, the table reports the t-statistic of the standard two-tailed ttest assuming unequal variance. 
Appendix 1: The development of co-operative membership in selected countries

\begin{tabular}{|l|l|l|l|l|}
\hline Country & $\begin{array}{l}\text { Number of co-op } \\
\text { members, } 1922\end{array}$ & $\begin{array}{l}\text { \% of population, } \\
1922\end{array}$ & $\begin{array}{l}\text { Number of co-op } \\
\text { members, 1998 }\end{array}$ & $\begin{array}{l}\text { \% of population, } \\
1998\end{array}$ \\
\hline UK & $4,559,000$ & $10.8 \%$ & $9,038,018$ & $15.3 \%$ \\
\hline Germany & $2,382,000$ & $4.6 \%$ & $21,640,000$ & $26.4 \%$ \\
\hline France & $2,300,000$ & $5.9 \%$ & $17,845,573$ & $30.3 \%$ \\
\hline Switzerland & 369,000 & $9.5 \%$ & $1,513,327$ & $21.3 \%$ \\
\hline Finland & 375,000 & $11.9 \%$ & $1,066,774$ & $20.7 \%$ \\
\hline Denmark & 376,000 & $12.3 \%$ & $1,392,244$ & $26.3 \%$ \\
\hline USA & n.a. & n.a. & $156,192,982$ & $57.8 \%$ \\
\hline Canada & n.a. & n.a. & $14,518,682$ & $47.9 \%$ \\
\hline India & n.a. & n.a. & $182,921,000$ & $18.7 \%$ \\
\hline Japan & n.a. & n.a. & $42,842,643$ & $33.9 \%$ \\
\hline
\end{tabular}

Sources: For 1922 figures for co-op membership, Gide (1922, p. 50); for 1998 membership, ICA (1998b); for population figures, Population Statistics at http://www.library.uu.nl/wesp/populstat/populframe.html Note: The number given for memberships should be regarded as indicative rather than exact. For both 1922 and 1998, the number of the members in co-operatives belonging to the International Cooperative Alliance (ICA) is provided, but this does not include unaffiliated co-operatives. On the other hand, no correction for multiple membership has been done. 
Appendix 2: Discussion on co-operatives at economic textbooks, by subject

\begin{tabular}{|c|c|c|c|c|c|c|}
\hline Author & Aschehoug & Westergaard & $\begin{array}{l}\text { v. d. } \\
\text { Borght }\end{array}$ & Conrad & Philippovich & Gide \\
\hline Publication year & 1903 & 1909 & 1909 & $1911-13$ & 1914 & 1919 \\
\hline $\begin{array}{l}\text { Book used in } \\
\text { teaching }\end{array}$ & $\begin{array}{l}\text { 1900s- } \\
1920 s\end{array}$ & 1910s & 1910s & $\begin{array}{l}\text { 1900s- } \\
1910 s\end{array}$ & 1900s-1930s & $\begin{array}{l}\text { 1900s- } \\
1930 \mathrm{~s}\end{array}$ \\
\hline $\begin{array}{l}\text { No. of pages } \\
\text { devoted to co- } \\
\text { operatives (\%) }\end{array}$ & $\begin{array}{l}36.25 / \\
2098 \\
(1.7 \%)\end{array}$ & $\begin{array}{l}6 / 203 \\
(3.0 \%)\end{array}$ & $\begin{array}{l}2 / 134 \\
(1.5 \%)\end{array}$ & $\begin{array}{l}47.5 / \\
1040 \\
(4.6 \%)\end{array}$ & $\begin{array}{l}13.75 \text { / } 612 \\
(2.2 \%)\end{array}$ & $\begin{array}{l}33.5 / \\
847 \\
(4.0 \%) \\
\end{array}$ \\
\hline $\begin{array}{l}\text { No. of pages } \\
\text { devoted to co- } \\
\text { operatives }+ \\
\text { related issues } \\
(\%)\end{array}$ & $\begin{array}{l}44 / 2098 \\
(2.1 \%)\end{array}$ & $\begin{array}{l}12.25 / 203 \\
(6.0 \%)\end{array}$ & $\begin{array}{l}2 / 134 \\
(1.5 \%)\end{array}$ & $\begin{array}{l}72 / 1040 \\
(6.9 \%)\end{array}$ & $\begin{array}{l}17.25 \\
(2.8 \%)\end{array}$ & $\begin{array}{l}43.5 \\
(5.1 \%)\end{array}$ \\
\hline General & 10.5 & & 0.25 & 2.5 & 2.5 & \\
\hline $\begin{array}{l}\text { Worker co- } \\
\text { operatives }\end{array}$ & 6.75 & 1 & 1 & 7.5 & 2.25 & 5 \\
\hline $\begin{array}{l}\text { Consumer co- } \\
\text { operatives }\end{array}$ & 8 & 2.25 & & 9 & 3.75 & 5 \\
\hline $\begin{array}{l}\text { Agricultural co- } \\
\text { operatives }\end{array}$ & 1.5 & 1 & 0.25 & 11 & 0.5 & 6 \\
\hline $\begin{array}{l}\text { Credit co- } \\
\text { operatives }\end{array}$ & 2.5 & 1.25 & & 9.5 & 3.75 & 7.5 \\
\hline $\begin{array}{l}\text { Mutual insurance } \\
\text { companies }\end{array}$ & 1.75 & 0.25 & & 4 & 0.5 & \\
\hline $\begin{array}{l}\text { Other types of } \\
\text { co-operatives } \\
\text { (e.g. housing, } \\
\text { construction) }\end{array}$ & & 0.25 & 0.25 & 4 & 0.5 & 1.5 \\
\hline Other & 5.25 & & 0.25 & & & 8.5 \\
\hline Related issues & & & & & & \\
\hline History of ideas & 2.25 & 3.5 & & & 3 & 0.5 \\
\hline $\begin{array}{l}\text { Profit-sharing } \\
\text { and employee } \\
\text { ownership }\end{array}$ & & 1.5 & & 6.5 & 0.25 & 6.5 \\
\hline Savings banks & 5.5 & 0.25 & & 18 & 0.25 & 3 \\
\hline $\begin{array}{l}\text { Co-operatives in } \\
\text { socialism (incl. } \\
\text { collective farms, } \\
\text { Yugoslav self- } \\
\text { management) }\end{array}$ & & 1 & & & & \\
\hline
\end{tabular}

Note: 1) Coverage given as the number of pages on the subject, unless otherwise noted. 
Appendix 2, continued

\begin{tabular}{|c|c|c|c|c|c|c|}
\hline Author & Marshall & Harmaja & Brisman & Willgren & Röpke & Leppo \\
\hline Publication year & 1920 & 1925 & 1925 & 1925 & 1951 & 1952 \\
\hline $\begin{array}{l}\text { Book used in } \\
\text { teaching }\end{array}$ & $\begin{array}{l}\text { 1930s- } \\
1950 \text { s }\end{array}$ & $\begin{array}{l}\text { 1930s- } \\
1950 \mathrm{~s}\end{array}$ & $1920 \mathrm{~s}$ & $\begin{array}{l}\text { 1920s- } \\
1930 \mathrm{~s}\end{array}$ & $1950 \mathrm{~s}$ & $\begin{array}{l}\text { 1950s- } \\
1970 \mathrm{~s}\end{array}$ \\
\hline $\begin{array}{l}\text { No. of pages } \\
\text { devoted to co- } \\
\text { operatives (\%) }\end{array}$ & $\begin{array}{c}4.75 / 722 \\
(0.7 \%)\end{array}$ & $\begin{array}{l}4.5 / 270 \\
(1.7 \%)\end{array}$ & $\begin{array}{l}3 / 198 \\
(1.5 \%)\end{array}$ & $\begin{array}{l}1.5 / 161 \\
(0.9 \%)\end{array}$ & 0 & $\begin{array}{l}1.25 / 202 \\
(0.6 \%)\end{array}$ \\
\hline $\begin{array}{l}\text { No. of pages } \\
\text { devoted to co- } \\
\text { operatives }+ \\
\text { related issues (\%) }\end{array}$ & $\begin{array}{l}5.5 \\
(0.8 \%)\end{array}$ & $\begin{array}{l}6.5 \\
(2.4 \%)\end{array}$ & $\begin{array}{l}3 \\
(1.5 \%)\end{array}$ & $\begin{array}{l}1.5 \\
(0.9 \%)\end{array}$ & 0 & $\begin{array}{l}2 \\
(1.0 \%)\end{array}$ \\
\hline General & & 1 & & 0.25 & & 0.75 \\
\hline $\begin{array}{l}\text { Worker co- } \\
\text { operatives }\end{array}$ & 3 & 0.5 & 0.5 & & & \\
\hline $\begin{array}{l}\text { Consumer co- } \\
\text { operatives }\end{array}$ & 0.5 & 0.75 & 2.25 & 0.5 & & \\
\hline $\begin{array}{l}\text { Agricultural co- } \\
\text { operatives }\end{array}$ & 0.5 & 1.25 & 0.25 & 0.25 & & \\
\hline $\begin{array}{l}\text { Credit co- } \\
\text { operatives }\end{array}$ & & 0.5 & & 0.25 & & 0.25 \\
\hline Mutual insurance & & 0.5 & & 0.25 & & \\
\hline $\begin{array}{l}\text { Other co- } \\
\text { operatives } \\
\text { (e.g. housing, } \\
\text { construction) }\end{array}$ & & & & & & \\
\hline Other & 0.75 & & & & & 0.25 \\
\hline Related issues & & & & & & \\
\hline History of ideas & & 1 & & & & 0.25 \\
\hline $\begin{array}{l}\text { Profit-sharing } \\
\text { and employee } \\
\text { ownership } \\
\end{array}$ & 1 & 0.5 & & & & \\
\hline Savings banks & & 0.5 & & & & 0.5 \\
\hline $\begin{array}{l}\text { Co-operatives in } \\
\text { socialism (incl. } \\
\text { collective farms, } \\
\text { Yugoslav self- } \\
\text { management) } \\
\end{array}$ & & & & & & \\
\hline
\end{tabular}

Note: 1) Coverage given as the number of pages on the subject, unless otherwise noted. 
Appendix 2, continued

\begin{tabular}{|c|c|c|c|c|c|c|}
\hline Author & Welinder & $\begin{array}{l}\text { Nyboe } \\
\text { Andersen, } \\
\text { Fog, } \\
\text { Winding }\end{array}$ & Boulding & Tamminen & Gerhard & Samuelson \\
\hline $\begin{array}{l}\text { Publication } \\
\text { year }\end{array}$ & 1953 & 1962 & 1966 & 1967 & 1968 & 1970 \\
\hline $\begin{array}{l}\text { Book used in } \\
\text { teaching }\end{array}$ & $\begin{array}{l}\text { 1940s- } \\
1950 \mathrm{~s}\end{array}$ & $\begin{array}{l}1950 s- \\
1960 \mathrm{~s}\end{array}$ & $\begin{array}{l}1950 \mathrm{~s}- \\
1960 \mathrm{~s}\end{array}$ & $\begin{array}{l}1960 \mathrm{~s}- \\
1970 \mathrm{~s}\end{array}$ & 1960s-1970s & 1970s-1980s \\
\hline $\begin{array}{l}\text { No. of pages } \\
\text { devoted to co- } \\
\text { operatives (\%) }\end{array}$ & $\begin{array}{l}3 / 530 \\
(0.6 \%)\end{array}$ & $\begin{array}{l}0.5 / 502 \\
(0.1 \%)\end{array}$ & $\begin{array}{l}1.75 / 693 \\
(0.3 \%)\end{array}$ & $\begin{array}{l}0.25 / 184 \\
(0.1 \%)\end{array}$ & $\begin{array}{l}0.25 / 309 \\
(0.1 \%)\end{array}$ & $0 / 835$ \\
\hline $\begin{array}{l}\text { No. of pages } \\
\text { devoted to co- } \\
\text { operatives + } \\
\text { related issues } \\
(\%)\end{array}$ & $\begin{array}{l}3.5 \\
(0.7 \%)\end{array}$ & $\begin{array}{l}1.25 \\
(0.2 \%)\end{array}$ & $\begin{array}{l}1.75 \\
(0.3 \%)\end{array}$ & $\begin{array}{l}0.5 \\
(0.3 \%)\end{array}$ & $\begin{array}{l}0.25 \\
(0.1 \%)\end{array}$ & $\begin{array}{l}0.5 \\
(0.1 \%)\end{array}$ \\
\hline General & 0.25 & 0.5 & 0.5 & & 0.25 & \\
\hline \multicolumn{7}{|l|}{$\begin{array}{l}\text { Worker co- } \\
\text { operatives }\end{array}$} \\
\hline $\begin{array}{l}\text { Consumer co- } \\
\text { operatives }\end{array}$ & 1.25 & & 1 & & & \\
\hline $\begin{array}{l}\text { Agricultural } \\
\text { co-operatives }\end{array}$ & 0.5 & & & & & \\
\hline $\begin{array}{l}\text { Credit co- } \\
\text { operatives }\end{array}$ & 0.5 & & 0.25 & 0.25 & & \\
\hline \multicolumn{7}{|l|}{$\begin{array}{l}\text { Mutual } \\
\text { insurance }\end{array}$} \\
\hline $\begin{array}{l}\text { Other co- } \\
\text { operatives } \\
\text { (e.g. housing, } \\
\text { construction) } \\
\end{array}$ & 0.25 & & & & & \\
\hline Other & 0.25 & & & & & \\
\hline \multicolumn{7}{|l|}{ Related issues } \\
\hline \multicolumn{7}{|l|}{ History of ideas } \\
\hline $\begin{array}{l}\text { Profit-sharing } \\
\text { and employee } \\
\text { ownership }\end{array}$ & & 0.25 & & & & \\
\hline Savings banks & 0.5 & & & & & \\
\hline $\begin{array}{l}\text { Co-operatives } \\
\text { in socialism } \\
\text { (incl. collective } \\
\text { farms, } \\
\text { Yugoslav self- } \\
\text { management) }\end{array}$ & & 0.5 & & 0.25 & & 0.5 \\
\hline
\end{tabular}

Note: 1) Coverage given as the number of pages on the subject, unless otherwise noted. 
Appendix 2, continued

\begin{tabular}{|c|c|c|c|c|c|c|}
\hline Author & Korpela & Lipsey & $\begin{array}{l}\text { Pekkarinen } \\
\& \text { Sutela }\end{array}$ & $\begin{array}{l}\text { Delander } \\
\text { \& Edebalk }\end{array}$ & $\begin{array}{l}\text { Baumol \& } \\
\text { Blinder }\end{array}$ & Begg et al. \\
\hline $\begin{array}{l}\text { Publication } \\
\text { year }\end{array}$ & 1978 & 1980 & 1980 & 1983 & 1988 & 1994 \\
\hline $\begin{array}{l}\text { Book used in } \\
\text { teaching }\end{array}$ & $\begin{array}{l}\text { 1970s- } \\
\text { 1980s }\end{array}$ & $\begin{array}{l}\text { 1960s- } \\
1980 \mathrm{~s}\end{array}$ & 1980s-1990s & $\begin{array}{l}\text { 1970s- } \\
\text { 1980s }\end{array}$ & 1980s-1990s & 1990s-2000s \\
\hline $\begin{array}{l}\text { No. of pages } \\
\text { devoted to co- } \\
\text { operatives (\%) }\end{array}$ & 0 & $\begin{array}{l}1.5 / 791 \\
(0.2 \%)\end{array}$ & 0 & $\begin{array}{l}1 / 378 \\
(0.3 \%)\end{array}$ & $\begin{array}{l}0 / 925 \\
(0 \%)\end{array}$ & $\begin{array}{l}0.5 / 639 \\
(0.08 \%)\end{array}$ \\
\hline $\begin{array}{l}\text { No. of pages } \\
\text { devoted to co- } \\
\text { operatives + } \\
\text { related issues } \\
(\%)\end{array}$ & 0 & $\begin{array}{l}1.5 \\
(0.2 \%)\end{array}$ & 0 & $\begin{array}{l}2.25 \\
(0.6 \%)\end{array}$ & $\begin{array}{l}1 \\
(0.1 \%)\end{array}$ & $\begin{array}{l}0.5 / 639 \\
(0.08 \%)\end{array}$ \\
\hline \multicolumn{7}{|l|}{ General } \\
\hline \multicolumn{7}{|l|}{$\begin{array}{l}\text { Worker co- } \\
\text { operatives }\end{array}$} \\
\hline $\begin{array}{l}\text { Consumer co- } \\
\text { operatives }\end{array}$ & & & & 0.25 & & \\
\hline $\begin{array}{l}\text { Agricultural } \\
\text { co-operatives }\end{array}$ & & 1.5 & & 0.25 & & \\
\hline $\begin{array}{l}\text { Credit co- } \\
\text { operatives }\end{array}$ & & & & 0.25 & & 0.5 \\
\hline \multicolumn{7}{|l|}{$\begin{array}{l}\text { Mutual } \\
\text { insurance }\end{array}$} \\
\hline $\begin{array}{l}\text { Other co- } \\
\text { operatives } \\
\text { (e.g. housing, } \\
\text { construction) }\end{array}$ & & & & 0.25 & & \\
\hline \multicolumn{7}{|l|}{ Other } \\
\hline \multicolumn{7}{|l|}{ Related issues } \\
\hline \multicolumn{7}{|l|}{$\begin{array}{l}\text { History of } \\
\text { ideas }\end{array}$} \\
\hline \multicolumn{7}{|l|}{$\begin{array}{l}\text { Profit-sharing } \\
\text { and employee } \\
\text { ownership }\end{array}$} \\
\hline Savings banks & & & & 0.25 & & \\
\hline $\begin{array}{l}\text { Co-operatives } \\
\text { in socialism } \\
\text { (incl. collective } \\
\text { farms, } \\
\text { Yugoslav self- } \\
\text { management) }\end{array}$ & & & & 1 & 1 & \\
\hline
\end{tabular}

Note: 1) Coverage given as the number of pages on the subject, unless otherwise noted. 